\title{
Embodying Memory / Mnemonic' Bodywriting: \\ Como un tatuaje 20th Century Latinamerican Songs
}

Encarnación de la memoria / escritura mnemónica en el cuerpo: Como un tatuaje, canciones latinoamericanas del siglo $\mathrm{xx}$

\section{Rodrigo Bazán Bonfil}

Universidad Autónoma del Estado de Morelos

rodrigo@uaem.mx

\section{Resumen}

Porque al menos Sara Montiel, Los Tres Diamantes, Joan Sebastian, Cheo Feliciano, K Paz de la Sierra, Elvis Crespo y Espinosa Paz interpretan canciones en que el tatuaje es la metáfora guía, el presente trabajo analiza, primero, la forma en que ésta varía en función del contexto, y luego cómo a partir de ella se construye un imaginario amoroso latinoamericano que abarca la segunda mitad del siglo xx e interpela a la corporeidad como memoria.

Palabras clave: lírica popular / género / cuerpo / memoria / imaginario amoroso / tatuaje como metáfora

\begin{abstract}
Since Sara Montiel, Los Tres Diamantes, Joan Sebastian, Cheo Feliciano, K Paz de la Sierra, Elvis Crespo and Espinosa Paz, to name a few, sing songs in which tattoos are a central metaphor, this work analyzes how they vary depending on the context and how they construct a Latin American imaginary loving that spans over the second half of the 20th century and challenges corporeity as memory.

Keywords: pop music / gender / body / memory / imaginary loving / tattoo as a metaphor
\end{abstract}

Fecha de recepción: 26 de noviembre de 2018 | Fecha de aceptación: 19 de febrero de 2019 
$\dot{2}$ Qué se deposita en un tatuaje? ¿Qué he depositado en los míos conforme se acumularon? ...el primero me lo hice una tarde de marzo mientras en Tijuana asesinaban al candidato presidencial Luis Donaldo Colosio: tinta en mi piel, plomo en su cabeza ¿Los tatuajes son, entonces, un registro histórico?

Tengo otros. Unos relacionados con mi hijo y la muerte de un amigo, y hace cuatro años acumulé siete u ocho en pocos meses porque elaboraba una ausencia amorosa; ninguno tiene el nombre de ella, por supuesto, pero la reafirmación que hacía de mí sí era un exorcismo. ¿Los tatuajes son, entonces, un apoyo mnemónico? Y si lo fueran, ¿resultan necesarios? ¿puedo, realmente, olvidar que mi amigo está muerto y mi hijo vivo? A ella, a su vez, no la olvidé (sé su nombre y sonrío cuando la pienso) pero ocupa un estante distinto que hace mucho no es altar.

La memoria y la historia personal se inscriben, pues, en una serie de espacios que percibimos ya como incorpóreos, ya como fisiológicos: saber en qué parte del cerebro se hallan los recuerdos de infancia o los planes para el futuro a mediano plazo no los vuelve más tangibles, más objetivos, más “cosas"; mientras sean devaneos del espíritu o reacciones químico-neuronales son como fantasmas. Una marca en la piel fija, en cambio, un estado de cosas que puede ser invocado una y otra vez y -como escribió Platón que Sócrates le contaba a Fedro que el Rey Tamus le había dicho al dios Teut sobre la escritura- no es

un medio para cultivar la memoria, sino para despertar reminiscencias [que justamente por eso es más útil, pues no] piensa transmitir un arte, consignándolo... como si estos caracteres pudiesen darle alguna instrucción clara y sólida [... sino] despertar reminiscencias en quien conoce ya el objeto de que se trata (Fedro $274 \mathrm{c}-277^{\mathrm{a}}$ )

y la curiosidad de quienes lo ignoran y aún cuando se tarden, inevitablemente, preguntarán: “¿y este tatuaje por qué te lo hiciste?” 


\section{Historiar contrariedades sin contrariar la Historia}

Les tatouages: étude anthropologique et médico-légale, de Alexandre Lacassagne, se publicó hace siglo y medio (o casi), mientras Du tatouage chez les prostituées, de Albert Le Blond y Arthur Lucas cuenta 120 años. Ambos textos fueron publicados en Tatuajes de criminales y prostitutas y se glosan a continuación porque testimonian visiones y prejuicios sobre los tatuados pero, sobre todo, porque recogen las biografías "desdeñables" de aquellos a quienes se envió a cumplir el servicio militar o a formarse en un taller elegido por sus padres, o bien fueron encerrados en cárceles y asilos, hospitales y reformatorios, colonias penitenciarias, de modo que las suyas -ajenas a los "grandes personajes" y casi a la Historia misma- son huellas biográficas de quien apenas tomó decisiones sobre sí; y cuando lo hizo, éstas fueron reprobables pues son criminales y putas cuyos nombres se conocen apenas, gente que seguramente escribió poco aunque las palabras sobre su piel lleguen hasta nosotros (N. de los E. 6).

Y si lo logran, -llegar hasta nosotros, quiero decir- lo consiguen porque el siglo XIX instrumenta la represión incitando a los discursos, a la multiplicación de las palabras, y se busca hacer hablar sin pausa, como en una expiación constante del interior de uno mismo para que se convierta en un exterior visible y controlable $(\mathrm{N}$. de los E. 7; ver además Foucault Historia de la sexualidad), mientras las cárceles -en general, pero aquellas donde se elaboraron ambos textos- se convierten en aparatos de saber donde los médicos forenses y psiquiatras que los elaboran son

denominados "especialistas del motivo" y deben apreciar ya no sólo la razón del sujeto sino la racionalidad de sus actos, y el conjunto de relaciones que los unen a sus intereses, cálculos, inclinaciones y hábitos como sujeto (Foucault, "La evolución de la noción de individuo peligroso...” citado por los editores)

La atención, por tanto, se centra en el sujeto, el acto se integra en una psicología particular y nace el individuo peligroso: una suerte de personaje-tipo caracterizado íntimamente por el riesgo, cuya actuación previa (lo que haya hecho) nunca es tan importante como lo que puede hacer. Luego, urge estudiarlo para detectar a quién se le parece, donde sea que esté, porque todos son virtualmente culpables (N. de 
los E. 9). Y en este escenario, el tatuaje -fácil de reconocer y difícil de ocultarpermite una rápida identificación física del criminal o la prostituta, por supuesto, pero sobre todo es también un atributo: exhibe una personalidad que, ligada a sus propias manifestaciones, responde al impulso e imperio de los sentimientos y por ello se considera un elemento importante para estudiar al "individuo peligroso": el tatuaje lleva a la piel lo que (según las buenas maneras) "debe" portarse en el fuero interno (N. de los E. 12-13).

Finalmente, el siglo xIx percibe el tatuaje como una muestra de escasa educación, de membresia en un oficio con sentido gremial muy fuerte, o de ambas característica pues generalmente se tatúan marineros, militares (los que ocupan las colonias, especialmente), herreros y prisioneros, mientras la privacía corpórea de las clases altas, que no se dejan desnudar como prostitutas y criminales para que se les censen tintas y cuerpos, hace a estos autores afirmar:

Uno de los últimos vestigios de la práctica del tatuaje en las clases altas obedece a las peregrinaciones a Jerusalén, pues aunque fue reprobada por la Iglesia, en Palestina la costumbre de tatuar símbolos religiosos existe todavía, y tenemos en nuestra colección el tatuaje de un hombre joven, hijo de uno de nuestros cónsules en Oriente, que fue allá en 1878, acompañado de príncipes maronitas; se tatuó junto con todos sus compañeros de viaje, y asegura que el gran duque de Rusia, Nicolás, llevaba dibujos similares. (Le Blond 86)

Visto, pues, como una marca infamante con que "en otros tiempos la justicia señalaba a los culpables", dado que después el Estado renunció a ello, Lucas y Le Blond concluyen:

Hoy la sociedad recompensa el coraje con una estrella y se reserva el derecho de arrebatársela a quien quiera deshonrarla [porque] nada es definitivo, y ninguna marca indeleble jamás debe ser grabada pues le quita al hombre el más preciado de los atributos de su individualidad: ¡la independencia y la libertad! (87) 


\section{Cantar dibujos: doble mediación}

Hurgo en la red y localizo catorce canciones: desde un bolero de 1951 a una bachata de 2015, pasando por merengues, ska, baladas y otras subespecies pop, vallenato, sones, música de banda; incluido algún texto en dos versiones y una tercera interpretación; ${ }^{1}$ setenta años de historia cultural latinoamericana que parecen un corpus suficiente porque son textos donde el tatuaje es metáfora guía para construir un imaginario "amoroso" que apela al cuerpo y la memoria.

Así, llama la atención que sólo dos sean canciones cantadas por mujeres y cómo la más antigua cumple casi todo lo descrito por Lacassagne -Sara Montiel da voz a una puta que repite las confesiones de un marino borracho como si fueran una "historia de amor"- y con ello asienta el primero de los modelos dominantes:

Él vino en un barco / de nombre extranjero. / Lo encontré en el puerto un anochecer ... / Era hermoso y rubio / como la cerveza / el pecho tatuado con un corazón. / Y ante dos copas de aguardiente / -sobre el manchado mostrador- / él fue contándome entre dientes / la vieja historia de su amor: / mira mi brazo tatuado / con este nombre de mujer. / ... Ella me quiso y me ha olvidado, / en cambio, yo no la olvidé / y para siempre voy marcado / con este nombre de mujer. (“Tatuaje”: Sara Montiel, 1963)

"Tú me marcas" es entonces el emblema de lo que otras canciones sobre amantes ausentes harán, con más o menos fortuna, entre 1996 y 2005. Desde las contradicciones lógicas del grupo Pegasso,

Sólo sé que a mi corazón no le han prohibido / dejar de amarte, dejar de amarte / si tus caricias se grabaron hasta en mi sangre / como un tatuaje, como un tatuaje (“Tatuaje": Grupo Pegasso, 2003)

\footnotetext{
${ }^{1}$ Ver al respecto "Cambiar la forma del canto: refuncionalización lírica en versiones, interpretaciones y covers".
} 
que (sólo) pueden rescatarse porque (de)muestran que la imagen es tópica hasta privilegiar el sentido de constancia que propone sobre el significado que el verso tenga o haya perdido; al guiño intertextual de Maldita Vecindad con Amado Nervo pero, sobre todo, a la manera en que el poema (la canción) cuestiona la idea del recuerdo como algo ajeno al cuerpo y afirma, en cambio, la permanencia, casi la inmortalidad de la persona a quien se haya amado en función de las marcas que (nos) deja en la piel:

Ana Ana Ana Ana Ana: / no eres un recuerdo, tú vives en mí. / Tengo tatuado tu nombre, / una rosa roja y un puñal / en mi pecho te llevo / vida, estamos en paz. (“Tatuaje”: Maldita Vecindad, 1998)

Los cuatro ejemplos restantes apuestan, en cambio, por un símil que ya repite el coro hasta terminar la canción, ya refrenda su sentido básico como alusión a "lo imborrable" en la memoria y el cuerpo, ya son descritos casi como las "estampitas" (calcomanías, adhesivos), que de tanto en tanto se regalan en los empaques de golosinas infantiles en México:

Y es que la llevo marcada en mi alma y en mi corazón / [coro] como un tatuaje / jay como un tatuaje!/ [coro] como un tatuaje/ ¡ay como un tatuaje!/ [coro] como un tatuaje. ("Como un tatuaje": Tony Tun Tun, 200o)

Sé que no voy a olvidarte, corazón, / porque te llevo muy dentro: / como un tatuaje del alma vives prendida en mi pecho. (“Tatuaje del alma”: Romualdo Brito, 2005)

Te necesito / y no es chantaje; / no sé si entiendas este lenguaje: / estás adherida a mí como un tatuaje. ("Como un tatuaje”: K-Paz de la Sierra, 2009)

de modo que el último - “Tatuajes”: Joan Sebastian, 1996- destaca, justamente, porque traiciona la imagen al evocar el placer que ella le dio e interiorizarlo de modo que siempre pueda recuperarlo:

A petición de tu orgullo / me iré ... pero eso de que te olvide / no sé. / Tatuajes de tus besos llevo / en todo mi cuerpo / tatuado sobre el tiempo / el tiempo que 
Rodrigo Bazán Bonfil

te conocí / se me hizo vicio ver tus ojos,/ respirar tu aliento / me voy pero te llevo dentro / de mí.

La memoria, entonces, deviene privilegio en vez de ser una marca impuesta por una voluntad ajena, y para hacerlo recupera su condición metafísica: si los besos tatuados son metáforas, evocarla no depende de mirar su nombre escrito y quien enuncia vuelve a ser socialmente aceptable: si no muestra en la piel lo que porta su fuero interno, no cumple la condición de "individuo peligroso".

El otro grupo grande: cinco canciones cuyo sustrato sería, al contrario, "yo te marco", cuenta también con una cantante pero el enunciado es mucho menos fuerte que en Tatuaje (1951: Los tres diamantes), la canción fundadora de toda la estirpe donde en contraste con el vaticinio edulcorado de Bibi Gaytán, lo que se halla es la voluntad de quien ama impuesta sobre la persona a quien dice amar:

A distancia tus labios tendrán / las noches tibias de tantos encuentros / y por la vida tú me llevarás / como un tatuaje fundido en tu cuerpo ("Como un tatuaje”: Bibi Gaytán, 1992)

Aunque no quieras yo he de seguirte por donde vayas / porque me llevas como un tatuaje dentro de tu alma. (“Tatuaje”: Los tres diamantes, 1951)

Fórmula cuyos ecos son claros en los sones de la última década, igualmente basados en símiles directos pero a los que se suma la auto exaltación del enunciador como amante y un comentario que distingue entre marcas definitivas y, quizá, dibujos hechos con gena:

No podrás olvidarme aunque lo intentes [...] como tatuaje me llevarás en ti (“Como tatuaje”: conjunto Aguazul, 2008)

No, no vas a olvidarme. / Tu primer beso tu primer amor / tu amor salvaje fui yo ... / Yo voy grabado en tu corazón / como un tatuaje [grita: i $y$ de ésos que no se borran, m’hija!] (“Como un tatuaje”: grupo AleBraJu, 2009)

Pero también alguna pieza de salsa compuesta al finalizar los 80, que despersonaliza a la amante para volverla puro cuerpo marcado, continua y permanente- 
mente poseído, además, porque la secrecía que envuelve el enunciado bandea entre la presunción de una lujuria mutua y compartida y algo como una complicidad mutua a partir de un juego de poder (¿una forma de humillación? ¿un abuso?) inconfesable pero igualmente tejida entre y por quienes participan del "juego" [ $\left.{ }^{\prime} !\right]$ :

Tu eterno amante yo seré / tu gran amor y tu pecado / algo prohibido, algo secreto / que llevarás en ti guardado. / Tu cuerpo lleva mis caricias / como si fueran mil tatuajes / que no se ven a simple vista / pero son huellas imborrables. / [Coro] Me quedo en ti / todo tu viaje / dentro de ti / como un tatuaje (“Como un tatuaje”: Cheo Feliciano, 1988)

Luego, al representar el tatuaje como marca erótica, la lírica contemporánea efectivamente pone en juego un imaginario colectivo prostibulario y delincuencial (al menos por contraste con las formas pulcras de galanteo), y simultáneamente romantiza los encuentros casuales con sexo:

Nuestro romance fue tan divino como un milagro / que sin pensarlo los dos vivimos intensamente ... No he de apartarme de tu memoria ni un solo instante / porque me llevas dentro de tu alma como un tatuaje. ("Tatuaje": Los tres diamantes, 1951)

[Coro] Le puso colores a mi vida cuando era gris. / Ella se marcó en vida ¿ahora qué será de mí? / [coro] ¿Y cómo la olvido si aún vive en mi corazón? / Yo no logro de mi mente arrancarla. / [coro] ¡Como un tatuaje marcada quedó! (“Como un tatuaje”: Tony Tun Tun, 2000)

Llegaste, entraste a mi corazón/ pero eso no te gustó. / Quieres ser sólo una amiga. / Me contaste de él / yo te conté de ella / ella me ama a mí / yo te amo a ti / y tú lo amas a él... / No sé si entiendas este lenguaje /estás adherida a mí como un tatuaje. ("Como un tatuaje": K-Paz de la Sierra, 2009)

De modo que se abre un último espacio discursivo, ajeno al marcaje y los actantes que su hacer había definido hasta ahora, cuyos extremos están en una separación que se enuncia como (inverosímil por) idealmente madura: 
¿Quién me lo diría? / se acabó / no fuiste tú, tampoco yo... fue un amor / de esos que nunca se olvidan ... Y en donde esté te llevaré / como un tatuaje como una herida ... / Siempre tendré de ti el mejor recuerdo / pero al extrañar / sé que voy a llorar. (“Como un tatuaje”: Elías Medina, 2010)

y un poema cuyo primer verso, explícito, es imperativo referencial que rompe los tratamientos previos del símil para ofrecer una erotización que de puro honesta (como placer del cuerpo) es cuasi porno: por ello tanto más divertida y ajena a mi corpus de análisis, pues se enuncia en presente y por ello es más plan inmediato que gesto mnemónico (aunque el tatuaje permanezca):

Hazte un tatuaje debajo del ombligo / con una flechita que diga que eso es mío. / Y yo te subo el traje; bebo de tu río / y con mi dedito te hago remolinos. / Y tu montañita yo la convierto en volcán / y con mi lengüita, lava le voy a sacar. (“Tatuaje”: Elvis Crespo, 2015)²

\section{Too \& Toos Tattoos ${ }^{3}$}

Asumido como práctica de los inaceptables, el tatuaje parece en su "origen" decimonónico occidental una ruptura con el Estado y su control, porque apoya la memoria en el cuerpo y con ello lo vuelve un mapa de los avatares -eróticos, pero no solamente- de quien los porta en vez de obligarle a -es más: salvándolo degenerar un discurso a propósito. Sobre un tatuaje sin escritura (id est, uno sin nombre) se puede, por ejemplo, contar una historia distinta a cada nuevx amante y ello conduce a ser permisivo, moralmente disoluto y sexualmente promiscuo; de

\footnotetext{
${ }^{2}$ Algunas críticas forzaron la creación de una versión edulcorada que, paradójicamente, no existe como grabación: "Hazte un tatuaje debajo del ombligo / con una flechita que me indique el camino. / Por ese paisaje bebo de tu río / sorbito a sorbito te hago remolinos. / Y tu montañita hoy la convierto en volcán / y con mis truquitos, magia te voy a sacar". Ver al respecto Brugueras, "Elvis Crespo graba una versión más light de su candente tema 'Tatuaje".

${ }^{3}$ La Lupita: Qué bonito es casi todo, RCA Music, 1994, track 13: https://www.youtube.com/ watch?v=cq4BFikghoE
} 
modo que para la medicina legal fue urgente apoderarse de esas historias y fijarlas para, en función suya, sentirse tranquila y moralmente superior: capaz de explicar asuntos que para los tatuados no eran un problema, pudo asumirse en capacidad de educar correctamente a las generaciones venideras.

El siglo xIx terminó, sin embargo, y conforme avanzó el xx la idea del tatuaje se incorporó en la lírica popular como una forma vicaria de amalditamiento y peligrosidad que, sin embargo, no renunció al ejercicio de poder que subyace en marcar a quien se dice amar "aunque sea sólo" mediante un nuevo discurso: los enunciadores no son ya prostitutas y criminales, mas no por ello son menos violentos o narran vínculos menos definitivos que los implicados en dibujarse la piel y ello es así porque, quizá, en la práctica y el canto del tatuaje perseguimos conservar una emoción que debió extinguirse pero en función de la cual se apuesta, en cambio, por una llama abrasadora y perenne que desde la perspectiva de la productividad capitalista es económicamente inútil porque, magister dixit, si bien,

esto se ha de revestir cuanto sea posible de los afectos propios, porque ningunos persuaden tanto como los verdaderamente apasionados [pues] la poesía es obra del ingenio o del entusiasmo, porque ... los de gran numen en todo son extremados. (Aristóteles, Poética 3:17)

también él dijo que la "pasión es una pena nociva y dolorosa" (3:10) que, como tal, difícilmente se aviene con horarios y deberes impuestos sobre la voluntad de aquellos que deciden ligar su identidad a sus propias manifestaciones, y responden al impulso e imperio de su sentimiento.

Los vaivenes entre lo público y lo privado se ven entonces, a la luz del tatuaje, como una lucha por la propiedad del cuerpo: ¿quién puede o no decidir sobre el suyo, en qué medida, con qué fines? No propongo, por supuesto, que llevar inscrito en el pecho el nombre de un(a) amante constituya una revolución última -por definición, ninguna podría serlo-, pero sí creo que aún hoy un gesto así pone en marcha formas de resistencia importantes; y que, al mismo tiempo, porque son inaccesibles para muchísimas personas, su representación lírica masiva constituye un espacio donde es posible vender la experiencia en la medida en que mientras se canta (por ejemplo en un karaoke) cualquiera de éstas es la propia historia de 
quien enuncia porque es quien extraña, porque es quien amó, porque es quien no olvida (aunque no va a tatuarse) porque es quien no se tatúa (ni consigue olvidar) porque... Luego, y al contrario de lo que Le Blond y Lucas argumentaban, justamente porque hoy nada es definitivo y hace mucho que la sociedad no "recompensa el coraje con una estrella", en las marcas indelebles que cada quien decida portar se deposita (o puede depositarse) "el más preciado atributo de su individualidad: la independencia y la libertad" para asegurar un recuerdo en el cuerpo y hacernos souvenir de nuestra propia historia. 
$\mathrm{W}$ hat do we place on a tattoo? What did I place on mine as they were piling up? ... I got the first one an afternoon in March, at the same time of day when somebody was shooting a presidential candidate in Tijuana... ink on my skin, lead in his head...Are tattoos then a form of historical records?

I got a few more. Some related to my son and the death of a dear friend, and four years ago, I added seven or eight which helped me mourn a new lover's departure. None bear her name, evidently, but the reaffirmation about myself which they were achieving was clearly an exorcism. Are tattoos, thus, a mnemonic support? And if they are, do we need them? Can I really forget that my friend is dead and my child alive? About her?, let's say that I never forgot her - I remember her name and I smile when I think of us, but she is on a separate shelf that ceased being an altar a long time ago.

Personal history and memories are written in a series of spaces that we sometimes perceive as incorporeal, and at times physiological. Knowing in which cerebral hemisphere we file childhood memories or future plans does not make them more tangible or objective, more like an object; as long as they are flirtations of the spirit or chemical-neurological reactions, they remain ghosts. A scratch and its mark fix instead a way of being, a state of things that we can summon over and over again, and just as King Tamus told the god Teut about writing- it is not a

...means to cultivate memory, but to awaken reminiscences [which is precisely why it is more useful, because it does not] intend to transmit an art [...] as if these characters could give some clear and solid instruction [... but] to awaken reminiscences in those who already know the object in question. (Plato, Fedro 274c-277a)

... as well as the curiosity of those who ignore it, and even perhaps a bit late, will ask: “iand this tattoo, why did you get it?"

\section{Storying Contrarians / Contradicting History}

Les tatouages: étude anthropologique et médico-légale, by Alexandre Lacassagne, and Du tatouage chez les Prostituées, by Albert Le Blond and Arthur Lucas, are 19th 
century books full of prejudice against tattooed people. However, they are equally important because they register the "expendable" lives (or "cases") of those who were sent to La Légion Étrangère, or to learn a craft in a workshop chosen by their parents, or were locked in jails, asylums, hospitals, reformatories and penal colonies. Consequently, their biographies - detached from "important" people and perhaps even History itself are about people who decided almost nothing for themselves; and when they did, those decisions were blameworthy because they were made by criminals and prostitutes whose names are virtually unknown; people who were practically illiterate but whose words have come to us through the skins.

And when they do reach us, it is because in the 19th century the repressive apparatus worked by inciting discourses, multiplying words, and seeking to make people speak without pause, as in a constant atonement within themselves. In these ways their inner lives became a visible and controllable exterior; the kind of "manageable" "object" that I mentioned earlier, when looking at tattoos as childhood landmarks. Meanwhile, prisons - in general, but especially those where Lacassagne, Le Blond and Lucas worked - became Institutions of knowledge where forensic doctors and psychiatrists were called

... "specialists of the motive" and had to consider not only the lucidity of the subjects but the rationality of their actions, and the set of relationships that bound them to their interests, calculations, inclinations and habits as a subject. (Foucault, About the concept of the "dangerous individual" in 19th century legal psychiatry)

Focus is therefore placed on the subject, the act is incorporated to a particular psychology and the dangerous individual is born: a kind of model character intimately typified by risk, whose previous action (whatever the individual has done) is never as important as what he can do: so, studying this kind of people is an urgent matter in order to detect who looks like them, wherever they are, because everyone is virtually guilty.

In this scenario, tattoos - easy to recognize, difficult to hide - allowed a quick physical identification of the criminal or the prostitute, but they are also an attribute: they expose a personality essentially linked to their own manifestations and that obeys to the empire of impulses and feelings. Thus tattoos were considered an 
important element of the study because, ultimately, tattoos bring to the surface of the skin what (according to good manners) "must" be worn inside ... and consequently becomes obscene by definition.

Finally tattoos in the 19th century were marks of a low education or of a trade marked by strong union ties such as sailors, soldiers (especially those in the colonies), blacksmiths and prisoners. On the other hand, the privacy of the body which characterized upper classes prevented them from having to be nude in front of the examiners. This allowed the authors to point out that

...one of the last vestiges of tattooing in the upper classes is due to the pilgrimages to Jerusalem, because although it was rejected by the Church, in Palestine the custom of tattooing religious symbols still exists, and we have in our collection the tattoo of a young man -son of one of our consuls in the East, who went there in 1878 accompanied by Maronite princes- who was tattooed along with all his traveling companions, and assures that the Grand Duke of Russia, Nicholas, wore similar drawings. (Le Blond, Introduction to Tatuajes de criminales y prostitutas)

Seen as an infamous branding with which "in other times justice marked the guilty", given the fact that the State put a halt to this practice, Lucas and Le Blond concluded that "today society rewards courage with a star and reserves the right to wrest it from anyone who wants to dishonor it [because] nothing is definitive, and no indelible mark should ever be engraved because it takes away from man the most precious of the attributes of his individuality: independence and freedom!"

\section{Singing Drawings: a Double Cultural Mediation}

Browsing the Internet I found fourteen songs: ranging from a 1951 bolero to a 2015 bachata, as well as merengue, ska, pop ballads, vallenato, sones, and banda 
music; these included a text in two versions and a third cover. ${ }^{1}$ All of this constitutes seventy years of Latin American cultural history, which seems a sufficiently wide corpus to study because they show tattoos as a guiding metaphor for constructing a so called imaginary "loving" that appeals to both body and memory. Thus, it is striking that only two songs are sung by women and also how the oldest matches almost everything described by Lacassagne: Sara Montiel gives voice to a whore singing the confessions of a drunken sailor, his "love story", exemplifying in this way the first of the two major discursive models in which Latin American pop songs represent tattooing.

He came in a ship with a foreign name / I found him one night at the port [...] He was beautiful and blond as beer / his chest tattooed with a heart [...] and after two glasses of whiskey he started telling bit by bit the old story of his love: / look at my tattooed arm with this woman's name [...] she loved me and forgot me / I didn't forget her / and forever I am marked with this woman's name. ("Tatuaje”: Sara Montiel, 1963)

I have your mark is then the emblem of what other songs about absent lovers will do, with more or less fortune, between 1996 and 2005. Starting with the logical contradictions of Pegasso which not only will make you laugh just because they show that the poetic image became a topic strong enough to privilege the sense of persistence that it proposes over the meaning that the verse has or has lost.

I only know that my heart hasn't been forbidden to stop loving you [...] if your caresses were engraved even in my blood as a tattoo, as a tattoo. ("Tatuaje": Grupo Pegasso, 2003)

Then we have the intertextual winks of Maldita Vecindad with Amado Nervo -Life I owe you nothing, at peace we are, life- in which the poem (the song) questions the idea of memory as something alien to the body and claims, instead, the permanence, almost the immortality, of the other through the marks that they leave on our skin.

${ }^{1}$ See "Cambiar la forma del canto: refuncionalización lírica en versiones, interpretaciones y covers". 
Ana Ana Ana Ana Ana: you are not a memory, you live in me / I have your name tattooed, a red rose and a dagger / in my chest I take you: life, at peace, we are. (“Tatuaje": Maldita Vecindad, 1998)

The last four examples, instead, bet on a simile that the chorus repeats until the song ends - and reiterates its basic meaning as an allusion to "the indelible" in the memory and the body - and in other cases describes tattoos almost as stickers that come in candy wraps.

So she's engraved in my soul and in my heart / chorus: just like a tattoo, oh! Just like a tattoo! (“Como un tatuaje”: Tony Tun Tun, 2000)

I need you and this is not blackmailing; / I don't know if you understand this language: / you are glued to me as a tattoo. (“Como un tatuaje": K-Paz de la Sierra, 2009)

The last quote stands out, precisely, because it betrays the image and instead of mourning the absence and underlining the skin marks as wounds, it evokes the pleasure they had together, and internalizes it so that it can always be retrieved.

.... at the request of your pride, I'm leaving [...] but the idea that I will forget you, I don't know: / tattoos of your kisses I carry all over my body / tattooed over the time, the time that I knew you were mine / Seeing your eyes / feeling your breath became a vice / I leave but I carry you inside with me. ("Tatuajes": Joan Sebastian, 1996)

In this way, memory becomes a privilege instead of being a mark imposed by the other, thus recovering its metaphysical condition. If tattooed kisses are metaphors, evoking a lost lover does not depend on looking at their written name, and whoever sings the song remains socially acceptable: if you don't show on the skin what you wear inside, you are not a "dangerous individual".

The other large group that we will examine is made up of five songs, the meaning of which would be, on the contrary, the figure I have marked you. In this group there is also female singer. But the claim in her song is weaker than the one in "Tatuaje" (Los Tres Diamantes,1951) the founding song of the entire lineage, where in contrast to the female singer's (Bibi Gaytán) sweetened prophecy, what we find is the will of a lover imposed on the other. 
Rodrigo Bazán Bonfil

At a distance your lips will have the warm nights of so many encounters / and trough life you will carry me / like a tattoo melted in your body. ("Como un tatuaje”: Bibi Gaytán, 1992)

Even if you don't want me to, I'll follow you wherever you go / because you carry me as a tattoo inside your soul. (“Tatuaje”: Los Tres Diamantes, 1951)

This form of echoes - I have marked you- resonate in the sones of the last decade, equally based on direct similes but with the addition of a self-exaltation of the enunciator as a lover, and a comment that distinguishes between definitive marks and henna tattoos.

You won't be able to forget me even if you try [...] as a tattoo you will carry me in you. ("Como un tatuaje”: Banda Aguazul, 2008)

No, you won't forget me / your first kiss, your first love, / your wild love was me [...] I am engraved in your heart / like a tattoo [...] shouts: and the kind that doesn’t disappear, m’hija! (“Como un tatuaje”: AleBraJu Group, 2009)

These echoes reach also a Salsa-style song, written at the end of the 80 , that depersonalizes the lovers turning them merely into a marked body - a fuck buddy who became a fuck body, would say Sreck Horvat -, continuous and permanently possessed because the secrecy that surrounds the statement oscillates between the presumption of mutual and shared lust, and some kind of a mutual complicity built on a game of power (a form of humiliation? an abuse?) unspeakable, but equally woven between and by those who "play the game" [i!].

I will be your eternal lover / your great love and your sin / something forbidden, something secret / that you will keep inside yourself [...] Your body carries my caresses / as a thousand tattoos / not visible to the naked eye / but that are indelible marks [...] chorus: I stay inside you / all along your journey / inside you / like a tattoo. ("Como un tatuaje": Cheo Feliciano, 1988)

By representing the tattoo as an erotic mark, contemporary lyrics effectively bring into play a collective imaginary of prostitution and delinquency (at least in 
contrast to the "neat" forms of courtship), and simultaneously romanticize sex and casual encounters.

... our romance was as divine as a miracle / that without thinking we both lived intensely [...] I will not move away from your memory for a single moment / because you carry me inside your soul like a tattoo. (“Tatuaje”: Los Tres Diamantes, 1951)

Chorus: she brought color to my life when it was gray / Tony: She marked my life, now what I will become? / chorus: and how do I forget her if she still lives in my heart? / Tony: I cannot rip her of my mind / chorus: she remains like a marked tattoo! (“Como un tatuaje”: Tony Tun Tun, 2000)

You came, you entered my heart / but you did not like that / you want to be just a friend / You told me about him / I told you about her / she loves me / I love you / and you love him [...] I do not know if you understand this language: / you are glued to me like a tattoo. ("Como un tatuaje": K-Paz de la Sierra, 2009)

As a consequence of granting casual encounters and wild sex, a romantic effect, a last discursive space opens up, oblivious to the marking and the subjects defined by it until now, whose extremes lie in a separation that is pronounced (implausible for being) ideally mature.

Who would have told me? / It's over / it wasn't you, nor me [...] It was a love / of those who are never forgotten [...] and wherever I go I will take you / like a tattoo, just like a wound [...] I will always have the best memory of you / but when I miss you / I know I'm going to cry. (“Como un tatuaje”: Elías Medina, 2010)

Finally, there is a poem whose first verse is an explicit referential imperative that breaks with the previous treatments of the simile to offer an erotization which, in its extreme honesty (as pleasure of the body), is almost pornographic, and therefore much more fun and alien to the corpus of my analysis, since it is in the present, and therefore it occurs in the realm of the immediate rather than as a mnemonic gesture (even if the tattoo remains). 
Rodrigo Bazán Bonfil

Get a tattoo under your navel / with a little arrow pointing out that that is mine / and I'll pull your dress up and drink from your river / and with my little finger I'll start making whirlpools / And your little mountain I will turn into a volcano / and with my tongue I'll bring out the lava. (“Tatuaje”: Elvis Crespo, 2015)²

\section{III. too \& toos tattoos}

Understood as an unacceptable practice, tattoos appeared in their Western 19th century's "origin" as a rupture with the State and its control because they support the memory in the body, and thus become a map of the avatars - the erotic vicissitudes, but not only - of the one who wears them instead of making them - in fact, saving us from- willfully generating a discourse. In the case of tattoos without writing (id est, one without a name) one can, for instance, tell a different story to each new lover, and this can lead to permissiveness, moral dissoluteness and sexual promiscuity. This is why it was urgent for legal medicine to seize those stories and fix them in order to feel calm and morally superior, capable of explaining issues that were not problematic for tattooed subjects, medicine felt ready to educate correctly the generations to come.

The 19 th century came to an end, however, and as the 2oth century advanced the figure of the tattoo was incorporated into popular lyrics as a vicarious form of dangerousness and amalditamiento (a self-bad-to-the-bone characterization) which, however, didn't renounce to the exercise of power that underlies the marking of the other, even if it is "merely" through a new discourse. The speakers are no longer prostitutes and criminals, but they are not less violent or narrate links less definitive than those involved in drawing on the skin. Perhaps, in the practice and singing of tattooing we seek to preserve emotions that should have disappeared long

\footnotetext{
${ }^{2}$ To attend some critical comments, Crespo rewrote the song, but has not recorded it: "Make a tattoo below your navel / with a little arrow that will show me the way / Through that landscape I drink from your river / sip by sip I make you whirlpools / And your little mountain today I turn it into a volcano / and with my tricks, magic I'm going to take you out". For more on this, see Melba Brugueras, "Elvis Crespo graba una versión más light de su candente tema 'Tatuaje”"
} 
ago, but instead, became a scorching and perennial flame that from the perspective of capitalist productivity is economically useless. As Magister dixit

... the poet should work out his play, to the best of his power, with appropriate gestures; for those who feel emotion are most convincing through natural sympathy with the characters they represent; and one who is agitated storms, one who is angry rages, with the most lifelike reality. Hence poetry implies either a happy gift of nature or a strain of madness. In the one case a man can take the mould of any character; in the other, he is lifted out of his proper self. (Poetics $3: 17$ )

Aristotle also said that "passion is a noxious and painful sorrow" (3:10) that, as such, hardly fits with schedules and duties imposed on the will of those who decide to link their identity to their own manifestations, and respond to the empire of impulses and feelings.

The swinging movements between the public and the private are then seen, in the light of tattooing, as a struggle for the ownership of the body: who can or cannot decide over their own body? up to what extent? for what purposes?

Evidently, I am not proposing that having the name of a lover inscribed on the chest constitutes an ultimate revolution - by definition, none could be - but I do believe that even today such a gesture sets in motion important forms of resistance. At the same time, because of the fact that they are inaccessible to many people, their massive lyrical representation constitutes a space where it is possible to sell the experience insofar as while you sing it (for example in a karaoke) any of the songs is the authentic story of the one that speaks, because she longs, because he is the one who loved, because she is the one who does not forget (although the speaker will not get tattooed), because she is the one who doesn't get tattooed (or cannot forget) because ... In the end, and contrary to what Lucas, Lacassagne and Le Blond argued, because today nothing is definitive and society stopped long ago "rewarding courage with a star". Now, in the indelible marks that each one decides to carry is deposited (or can be deposited) "the most precious attribute of individuality: independence and freedom" in order to save a memory in the body and make us souvenirs of our own history. 


\section{Rodrigo Bazán Bonfil}

Estudió Literatura Hispánica en la UnAM y el Colegio de México donde elaboró, respectivamente, tesis sobre el Bolero como discurso amoroso y sobre el horror en Romances de pasión sexual y violencia. Hace catorce años que trabaja para la UAEM, es miembro del SNI, ha sido profesor invitado en los posgrados de las Universidades Iberoamericana, Autónoma Metropolitana-Ixtapalapa, del Claustro de Sor Juana, y El Colegio de San Luis. Sus líneas de investigación son Líricas popular y tradicional panhispánicas (del romance medieval al reguetón panameño cruzando por los corridos mexicanos y la radio contemporánea); Soportes, consumo y transmisión cultural (relaciones entre oralidad, escritura, web, derecho de autor, construcción del cánon); Género y Cultura Popular (recientemente, analizo cómo los medios hacen permanente una serie de relaciones de poder que creo deben modificarse); y Teoría y Crítica de las humanidades (CA).

\section{OBRA CITADA}

Aristóteles, El arte poética, traducción del griego, prefacio y notas de José Goya y Muniain. Buenos Aires: Austral, 1948.

Aristóteles, Poetics, traducción de S. H. Butcher, Liberty Online. Web. 25 November 2018. http://libertyonline.hypermall.com/Aristotle/Poetics.html.

Bazán, Rodrigo, "Cambiar la forma del canto: refuncionalización lírica en versiones, interpretaciones y covers", M. Reinoso (ed.), Tradiciones y culturas populares. Grupo Destiempos: México, 2008: 96-114. Web. 25 November 2018. http://www. destiempos.com/n15/rbazan_15.htm.

Brugueras, Melba, "Elvis Crespo graba una versión más light de su candente tema Tatuaje", Primera hora, noviembre 19 del 2014. Web. 25 November 2018. https:// www.primerahora.com/entretenimiento/musica/nota/elviscrespograbaunaversionmaslightdesucandentetematatuaje-1048666/ 
Foucault, Michel, "La evolución de la noción de individuo peligroso en la psiquiatría legal del siglo xix", en Estética, ética y hermenéutica. Barcelona: Paidós, 1999.

Lacassagne, Alexandre, "El tatuaje en los criminales", en Tatuajes de criminales y prostitutas. Errata Naturae, Madrid, 2012: 15-73. Impreso.

Le Blond, Albert \& Arthur Lucas, "Sobre el tatuaje en las prostitutas", en Tatuajes de criminales y prostitutas. Errata Naturae, Madrid, 2012: 75-165. Impreso.

"Nota de los editores", en Tatuajes de criminales y prostitutas. Madrid: Errata Naturae, 2012: 5-13.

Platón, Fedro, Isabel Blanco (ed.), Patricio Azcárate (trad.) Torre de Babel ediciones. We. 25 November 2018. http://www.e-torredebabel.com/Biblioteca/Platon/ Platon.htm 


\section{Rodrigo Bazán Bonfil}

\section{CANCIONES CITADAS}

\begin{tabular}{|c|c|c|c|}
\hline \multicolumn{4}{|c|}{ LISTA DEL CORPUS ANALIZADO } \\
\hline Año & Título & Intérprete & Localización de los videos (URL) \\
\hline 1951 & Tatuaje & $\begin{array}{l}\text { Los tres } \\
\text { diamantes }\end{array}$ & https://www.youtube.com/watch?v=AEsXl0rNRnA \\
\hline 1963 & Tatuaje & Sara Montiel & https://www.youtube.com/watch?v=_L4zpARiucM \\
\hline 1988 & Como un tatuaje & Cheo Feliciano & https://www.youtube.com/watch?v=44qcacvvhUw \\
\hline 1992 & Como un tatuaje & Bibi Gaytán & https://www.youtube.com/watch?v=jEvrZAkeDN0 \\
\hline 1994 & Too \& Toos Tatoos & La Lupita & https://www.youtube.com/watch?v=cq4BFik9hOE \\
\hline 1996 & Tatuajes & Joan Sebastian & https://www.youtube.com/watch?v=SM_jy0PimAA \\
\hline 1998 & Tatuaje & $\begin{array}{l}\text { Maldita } \\
\text { Vecindad }\end{array}$ & https://www.youtube.com/watch?v=URas25c0adI \\
\hline 2000 & Como un tatuaje & Tony Tun Tun & https://www.youtube.com/watch?v=3pkrdyUir04 \\
\hline 2003 & Tatuaje & Grupo Pegasso & https://www.youtube.com/watch?v=3hhZ5PR5Ho0 \\
\hline 2005 & Tatuaje del alma & Romualdo Brito & https://www.youtube.com/watch?v=QyWkls9ii4U \\
\hline 2007 & Tatuaje del alma & Pepe Guerra & https://www.youtube.com/watch?v=C_eeT_tAEuY \\
\hline 2008 & Como tatuaje & $\begin{array}{l}\text { Conjunto } \\
\text { Aguazul }\end{array}$ & https://www.youtube.com/watch?v=NwHggT-obrQ \\
\hline 2009 & Como un tatuaje & Grupo AleBraJu & https://www.youtube.com/watch?v=-YkRn706adg \\
\hline 2009 & $\begin{array}{l}\text { Como un tatuaje (Tatuaje } \\
\text { del alma) }\end{array}$ & La Élite & https://www.youtube.com/watch?v=emMaF0LlM-E \\
\hline 2009 & Como un tatuaje & $\begin{array}{l}\text { K-Paz de la } \\
\text { Sierra }\end{array}$ & https://www.youtube.com/watch?v=UYtpMW1CQUM \\
\hline 2010 & Como un tatuaje & Elías Medina & https://www.youtube.com/watch?v=UfrZhh5tAAA \\
\hline 2015 & Tatuaje & Elvis Crespo & https://www.youtube.com/watch?v=cAN9Pk_CC-8 \\
\hline
\end{tabular}

